\title{
Pilot application of drone observations and pigment marker detection by HPLC in studies of cyanobacterial harmful algal blooms in Bulgarian inland waters
}

\author{
Maya P. Stoyneva-Gärtner ${ }^{\mathrm{A}}$, Blagoy A. Uzunov ${ }^{\mathrm{A}, \mathrm{E}}$, Jean-Pierre Descy ${ }^{\mathrm{B}}$, \\ Georg Gärtner $^{\mathrm{C}}$, Petya H. Draganova ${ }^{\mathrm{A}}$, Cvetanka I. Borisova ${ }^{\mathrm{A}}$, Vera Pavlova \\ and Maria Mitreva ${ }^{\mathrm{D}}$ \\ A Sofia University 'St Kliment Ohridski', Faculty of Biology, Department of Botany, \\ 8 Boulevard Dragan Zankov, BG-1164, Sofia, Bulgaria. \\ ${ }^{B}$ Université de Liège, Unité d'Océanographie Chimique, Sart Tilman, BE-4000, Liège, Belgium.

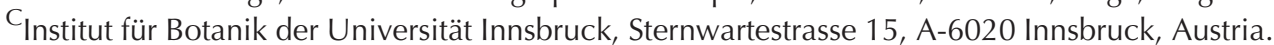 \\ D National Centre of Public Health and Analyses, Boulevard Akademik Ivan Evstratiev Geshov 15 \\ BG-1431, Sofia, Bulgaria. \\ ${ }^{\mathrm{E}}$ Corresponding author. Email: buzunov@uni-sofia.bg
}

\begin{abstract}
This paper describes the first use of aerial observations by a drone as an additional means for choosing sampling points during field studies of cyanobacterial harmful algal blooms (CyanoHABs) in selected Bulgarian waterbodies and the use of HPLC analysis of marker pigments for the fast determination of phytoplankton composition and biomass. The selection of waterbodies was based on the authors' personal expertise and data collected over a 25 -year period. In all sites chosen by drone, there were high levels of cyanobacteria and cyanotoxins were present: microcystins (MC-LR, MC-RR, MC-YR in Durankulak Lake and MC-LR and MC-RR in the Sinyata Reka Reservoir), cylindrospermopsin (in the Vaya Lake and in the Mandra Reservoir) and saxitoxins (in Durankulak Lake). The finding of cylindrospermopsin is the first in Bulgaria, the detection of saxitoxins is the first for Durankulak Lake and the microcystins records are the first for Sinyata Reka Reservoir. Considering the high total number of wetlands in Bulgaria, many of which are lowland, small and shallow and therefore vulnerable to CyanoHABs, we recommend further use of drones and HPLC in monitoring, which should speed up detection and reduce sampling efforts while enabling valuable information to be gathered.
\end{abstract}

Additional keywords: cyanobacteria, cyanoprokaryotes, cyanotoxins, cylindrospermopsin, microcystins, phytoplankton, saxitoxins.

Received 1 October 2018, accepted 19 February 2019, published online 14 May 2019

\section{Introduction}

The phylum Cyanoprokaryota (Cyanobacteria), known also as blue-green algae, represents a group of peculiar prokaryotic phototrophs without developed plastids that are widespread in all types of aquatic and aeroterrestrial habitats (Graham et al. 2009; Whitton and Potts 2012). Some cyanoprokaryotes are hazardous, causing environmental and human health problems during their mass development, which is commonly referred to as a blooms (Paerl 2001; Merel et al. 2013). Their negative effects are due mostly to the production of strain-specific, genecontrolled toxic metabolites (cyanotoxins), which have adverse acute or chronic health effects on mammals (including humans) and other organisms (including plants; Codd et al. 1989, 1999, 2005a, 2005b; Carmichael 1994; Codd 1995; World Health Organization 1998; Chorus and Bartram 1999; Maršálek et al. 2000; Meriluoto and Codd 2005; Mitrovic et al. 2005; Metcalf and Codd 2012; Merel et al. 2013; Walker 2015; Liyanage et al.
2016). Therefore, the common term 'harmful algal blooms' (HABs) is used for blooms dominated by cyanoprokaryotes (abbreviated as CyanoHABs, C-HBs or cHAbs; e.g. Paerl et al. 2011; Carmichael and Boyer 2016). These blooms are perceived as one of the most dangerous threats for our future, ironically referred to as the 'blue-green future' (Elliott 2012).

Despite this general knowledge, which has high public recognition, and despite considerable advances in the detection and analysis of cyanotoxins, with vast amounts of data collected, numerous problems still remain. A lot of work has to be done to discover and better understand the taxonomy and biology of different causative agents, toxins and toxic effects, toxin cell quotas, all driving forces, risk assessments and the socioeconomic and ecological costs of CyanoHABs, which are largely unmeasured (e.g. Roelke and Buyukates 2001; Van Dolah et al. 2001; Mowe et al. 2015; Carmichael and Boyer 2016). 
At the same time, the scientific tools, devices and methods used in CyanoHAB studies are constantly improving. HPLC determination of marker pigments is a useful tool for the rapid assessment of phytoplankton biomass and composition at the phylum and class levels (e.g. Jeffrey et al. 1997; Wright and Jeffrey 2006). Originally developed in marine studies, HPLC determination of marker pigments has been successfully used in studies of estuaries (e.g. Paerl et al. 2003) and fresh waters, in ecological studies (e.g. Descy et al. 2000; Schlüter et al. 2006) and, in combination with microscopic assessment of dominant taxa and determination of functional groups (Reynolds et al. 2002), to assess lake status (Sarmento and Descy 2008) and estimate cyanobacterial biomass (Descy 2017). An example of the successful application of the pigment technique for the quantification of cyanoprokaryotes and cyanobacteria can be found in Van Wichelen et al. (2010), where cyanobacterial contribution as determined by HPLC with CHEMTAX software (CSIRO Marine Laboratories, Hobart, Tas., Australia; Mackey et al. 1996) was well correlated with Microcystis spp. biomass in a hypertrophic lake. Recently, studies of CyanoHABs, as well as the monitoring and removal and wetland assessments of CyanoHABs, have made use of available optical remote sensing, geographic information system (GIS)-based methods and modern field sampling devices (e.g. Gons et al. 2005; Williams 2014; Boon et al. 2016; Jung et al. 2017; Ragueno et al. 2017). However, no single method seems sufficient for the accurate monitoring of blooms. It is broadly accepted that all approaches need to be tailored for specific waterbodies using methods based on economic feasibility, speed, sensitivity and field applicability, with an emphasis on early-warning systems for the detection of toxigenic algal populations (Codd et al. 2005b; Srivastava et al. 2013). Beyond doubt, the timing and speed of the invention, development and application of these techniques differs and is primarily related to the economic development of the affected countries.

Bulgaria is an Eastern European country with a temperate climate, positioned in a biodiversity hot spot of the Balkan peninsula, with numerous waterbodies, including important drinking water reservoirs, recreational sites and protected areas (Michev and Stoyneva 2007). Although Bulgaria has a high number of waterbodies $(\sim 8900)$, they are small and their surface area of $\sim 112000$ ha covers less than $0.1 \%$ of the entire country (Michev and Stoyneva 2007). The waterbodies in Bulgaria are situated primarily in the lowlands (Michev and Stoyneva 2007). Most are shallow and therefore quite vulnerable to human impact caused primarily by strong agricultural activities in the country; 340 are included in the Red List of Bulgarian wetlands (Michev and Stoyneva 2007). Algological studies in Bulgaria started at the end of 19th century (Petkoff 1898) and, since the first decades of the 20th century, blooms of blue-green algae were identified in different waterbodies with suggestions as to their toxic character (Stoyneva 2014; Descy et al. 2018; Dimitrova et al. 2018 and references therein). Since the beginning of the 21 st century, 61 of the 115 waterbodies studied have been found to be susceptible to CyanoHABs, with more than 42 toxinproducing taxa found, in addition to the detection of microcystins, nodularins and saxitoxins by HPLC, ELISA and cytotoxicological tests (Stoyneva-Gärtner et al. 2017; Descy et al. 2018). All these results were based on standard phytoplankton sampling and conventional microscopy, and indicated the need for further permanent monitoring and studies based on modern sampling and research methods (Stoyneva-Gärtner et al. 2017; Descy et al. 2018). Therefore, the aim of the present study was to use aerial observations from a drone equipped with a camera as an additional way of choosing sampling sites during field studies of CyanoHABs in Bulgarian inland waters, in combination with HPLC analysis of marker pigments for fast determination of phytoplankton.

\section{Materials and methods}

The study was conducted from 20 to 27 June 2018 in nine shallow (mean depth 0.5-2 m) lowland waterbodies, situated in central and eastern Bulgaria (Fig. 1; Table 1). This earlysummer period was chosen because of an atypical extremely dry and warm spring in the country (with temperatures up to $31^{\circ} \mathrm{C}$ in April and May). However, unexpectedly, the sampling days were preceded by strong rainfalls and floods along the Black Sea coast. The waterbodies and the main sampling sites were chosen according to all results from previous studies, which indicated a threat of CyanoHABs, as summarised by Stoyneva-Gärtner et al. (2017) and Descy et al. (2018) and based on 25 years of expertise of the authors in studies on phytoplankton and cyanotoxins in most of these waterbodies (Stoyneva 2000a, 2000b, 2003, 2014, 2016; Pavlova et al. 2006, 2007, 2014; Dimitrova et al. 2014a, 2014b; Stoyneva et al. 2015; Stoyneva-Gärtner et al. 2017). Detailed descriptions of the morphometry, historical development, use, conservation status and biodiversity of each of the waterbodies are provided in the Database of Bulgarian wetlands in the Inventory of Bulgarian wetlands and their biodiversity (Michev and Stoyneva 2007). Table 1 provides the unique inventory number for each waterbody from this database (IBWXXXX).

After reaching the target site at the shore of the chosen waterbody, before sampling a drone equipped with a camera was sent to observe and document the whole waterbody and possible hot spots indicated by colour differences. The drone used was DJI Mavic Pro (Model M1P GL200A; SZ DJI Technology, Shenzhen, PR China). The records were stored as photographs and videos. Decisions were made on the basis of aerial photographs obtained by remote sensing without any attempt to correct data for surface reflection etc. Spots or areas of different colour were chosen for sampling (Fig. 2) or, in case of visible water homogeneity, sampling was done at the same sites as in previous studies (Stoyneva 2000a, 2000b, 2003, 2014; Pavlova et al. 2006, 2007, 2013, 2014, 2015; Dimitrova et al. 2014a, 2014b; Stoyneva et al. 2015; Stoyneva-Gärtner et al. 2017). All sampling sites were reached by inflatable boat, with engine and oars, used according to site characteristics.

Water transparency was measured using a Secchi disc (in accordance with the requirements of Bulgarian monitoring legislation: State Order for characterisation of the surface waters of the Minister of Environment and Waters of Bulgaria $\mathrm{N} \mathrm{4/14.09.2012).} \mathrm{The} \mathrm{site} \mathrm{coordinates,} \mathrm{altitude,} \mathrm{water} \mathrm{tempera-}$ ture, $\mathrm{pH}$, dissolved oxygen (DO), total dissolved solids (TDS) and conductivity were measured in situ using an Aquameter AM-200 and Aquaprobe AP-2000 (Aquaread Water Monitoring Instruments, Broadstairs, UK). 


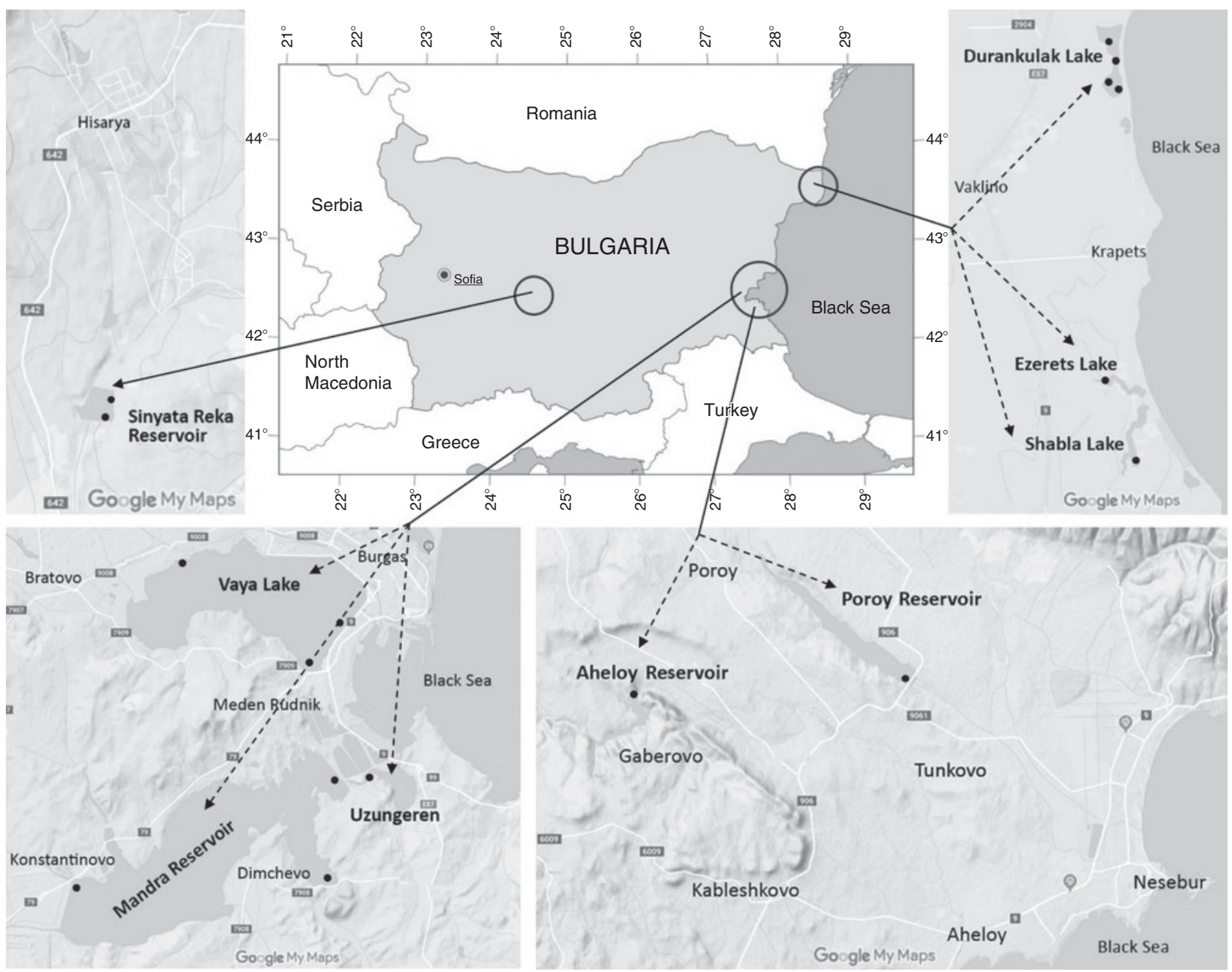

Fig. 1. Map of Bulgaria showing the sampling sites (modified after http://www.ginkgomaps.com, accessed 28 September 2018).

Total nitrogen (TN) and total phosphorus (TP) were measured ex situ using an Aqualytic AL410 Photometer from (AQUALYTIC, Dortmund, Germany). The TN: TP ratio was used to assess nutrient limitation according to Forsberg et al. (1978) and Overbeck (1988), where values above 12 indicate $\mathrm{P}$ limitation, values below 7 indicate $\mathrm{N}$ limitation and values between 7 and 12 indicate that either of the nutrients may be limiting.

Following the basic guidelines for the detection and monitoring of toxic cyanobacteria (Salmaso et al. 2017), HPLC analysis was used to estimate biomass by marker pigment analysis, as described in detail by Descy (2017, SOP5). Water samples were filtered through Macherey-Nagel GF5 filters (porosity $0.7 \mu \mathrm{m}$, Macherey-Nagel GmbH \& Co. KG, Düren, Germany) and placed in $8 \mathrm{~mL}$ of $90 \%$ acetone (HPLC grade) in centrifugation tubes. For pigment extraction, samples were subjected to two 15 -min periods of sonication (in a sonication bath containing melting ice) separated by overnight incubation at $4^{\circ} \mathrm{C}$. Pigments were analysed using a Waters (Milford, MA, USA) HPLC system equipped with diode array detection. Calibration was made using commercial external standards of carotenoids and chlorophylls (DHI, Hoersholm, Denmark). Chromatograms were processed and quantified using Empower software (Sean O'Sullivan, Otago University, Auckland, New Zealand) and pigment concentrations were processed using CHEMTAX software (CSIRO Marine Laboratories; Mackey et al. 1996), enabling estimation of the contribution of phytoplankton classes and phyla to chlorophyll (Chl)- $a$. Data processing followed a procedure similar to that of Sarmento and Descy (2008), enabling estimation of the relative proportion of green algae, chrysophytes, diatoms, cryptophytes, dinoflagellates and cyanoprokaryotes or cyanobacteria in the biomass, expressed per unit volume $\left(\mu \mathrm{g} \mathrm{Chl}-a \mathrm{~L}^{-1}\right)$. These taxonomic groups were separated according to the pigments, indicated in the initial ratio matrix (Table 2) used in the CHEMTAX processing, similar to that of SOP5 (Descy 2017).

Total Chl- $a$ was used as a proxy of total algal biomass in the evaluation of trophic status according to the Open-Boundary System of the Organization for Economic Cooperation and Development (Vollenweider and Kerekes 1982; Vollenweider 1993). 


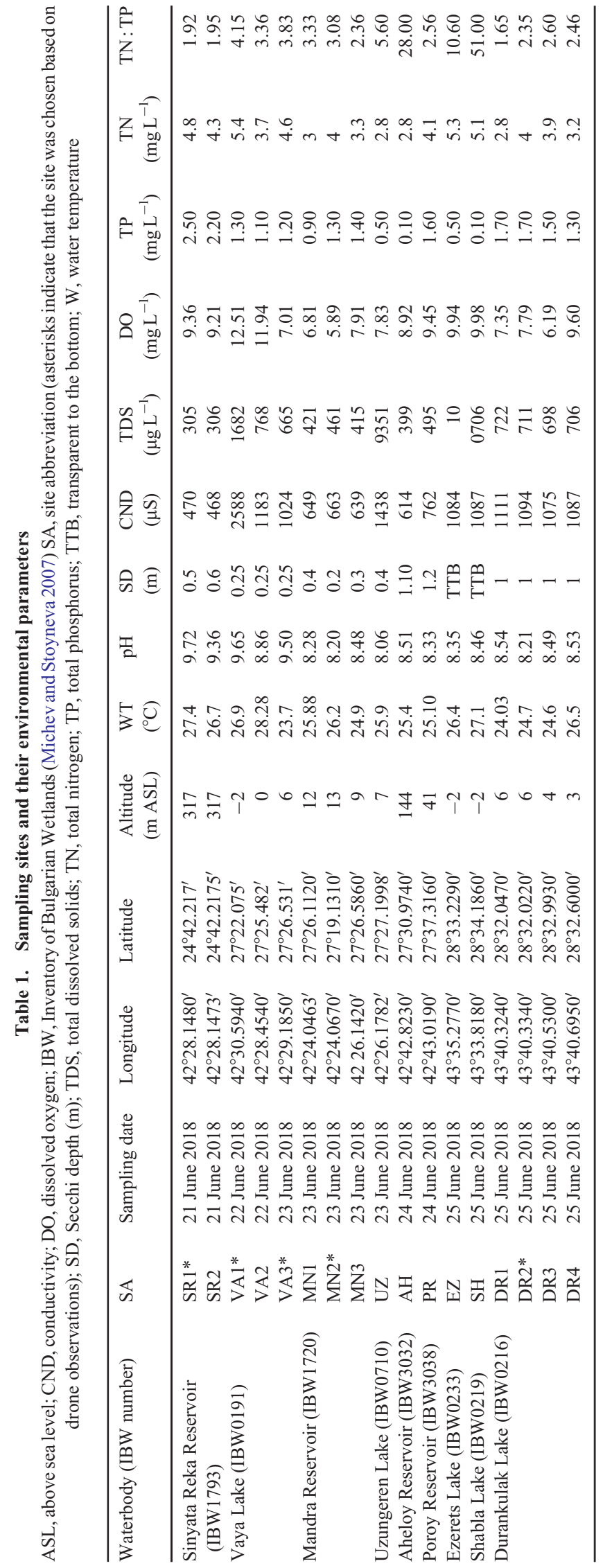

A principal components analysis (PCA) was run using Statistica 10 (StatSoft Inc., Tulsa, OK, USA) to examine the relationships among limnological and phytoplankton variables and to establish a classification of the lakes according to the main environmental gradient.

For detection of microcystins, nodularins, saxitoxins and cylindrospermopsins, the recommendations of Ballot et al. (2017), Catherine et al. (2017) and Kokociński et al. (2017a) were followed. Owing to possible variations in methods, more details are provided below, with a note that the methods used are completely compatible with those from our previous studies (for details, see references in Stoyneva-Gärtner et al. 2017). For microcystin and nodularin determination, stored water samples were frozen and thawed three times to achieve cell lysis. Next, samples were filtered through $0.45-\mu \mathrm{m}$ nylon membrane filters (Alltech Associates Inc., Deerfield, IL, USA). Microcystins and nodularin were extracted from water samples by solid-phase extraction with Empore Extraction Disks C-18 (Varian, Darmstadt, Germany). Toxins were eluted with methanol. Eluates were dried by a gentle stream of nitrogen, redissolved in $500 \mu \mathrm{L}$ of $50 \%$ methanol $(\mathrm{v} / \mathrm{v})$, filtered through $0.22-\mu \mathrm{m}$ polytetrafluoroethylene (PTFE) syringe filters (ALBET LabScience, Dassel, Germany) and analysed by HPLC according to ISO 20179:2005 (International Organization for Standardization 2005).

The HPLC system for quantitative and qualitative analyses included an Agilent 1200 Series coupled with a diode array detector (DAD; Agilent Technologies, Santa Clara, CA, USA). Toxins were analysed on a Supelcosil ABZ+Plus column $(150 \times 4.6 \mathrm{~mm}, 5 \mu \mathrm{m}$; Supelco, Inc., Bellefonte, PA, USA). The binary gradient of the mobile phase consisted of Milli-Q water $+0.1 \%$ trifluoroacetic acid (TFA) (A) and acetonitrile $+0.1 \%$ TFA (B), with a linear increase from $20 \%$ $\mathrm{B}$ at $0 \mathrm{~min}$ to $46 \% \mathrm{~B}$ at $25 \mathrm{~min}$ and stop time at $30 \mathrm{~min}$; the flow rate was $1 \mathrm{~mL} \mathrm{~min}^{-1}$ and samples were run at temperature $25^{\circ} \mathrm{C}$. Chromatograms were recorded at $238 \mathrm{~nm}$ and toxins were identified by the retention time and characteristic ultraviolet (UV) absorption spectra from 200 to $300 \mathrm{~nm}$.

Purified microcystins MC-LR, MC-RR, MC-YR and nodularin (Abraxis, Inc., Warminster, PA, USA) were used as external standards.

Cylindrospermopsin and saxitoxins were detected using specific antibodies in stored frozen water samples by ELISA. Cylindrospermopsin, when present in a sample, and a horseradish peroxidase (HRP)-conjugated cylindrospermopsin analogue compete for the binding sites of rabbit anticylindrospermopsin antibodies in solution. The anticylindrospermopsin antibodies are then bound by a secondary antibody (goat anti-rabbit) immobilised on the wells of the microtitre plate. Saxitoxin, when present in a sample, and a saxitoxin-enzyme conjugate compete for the binding sites of rabbit anti-saxitoxin antibodies in solution. The saxitoxin antibodies are then bound by a secondary antibody (sheep anti-rabbit) immobilised on the plate. After a washing step and the addition of substrate solution, a colour signal (blue) is generated. The intensity of the blue colour is inversely proportional to the concentration of cylindrospermopsin or saxitoxins present in the sample. The colour reaction is stopped after a specified time and the colour is evaluated using an ELISA 

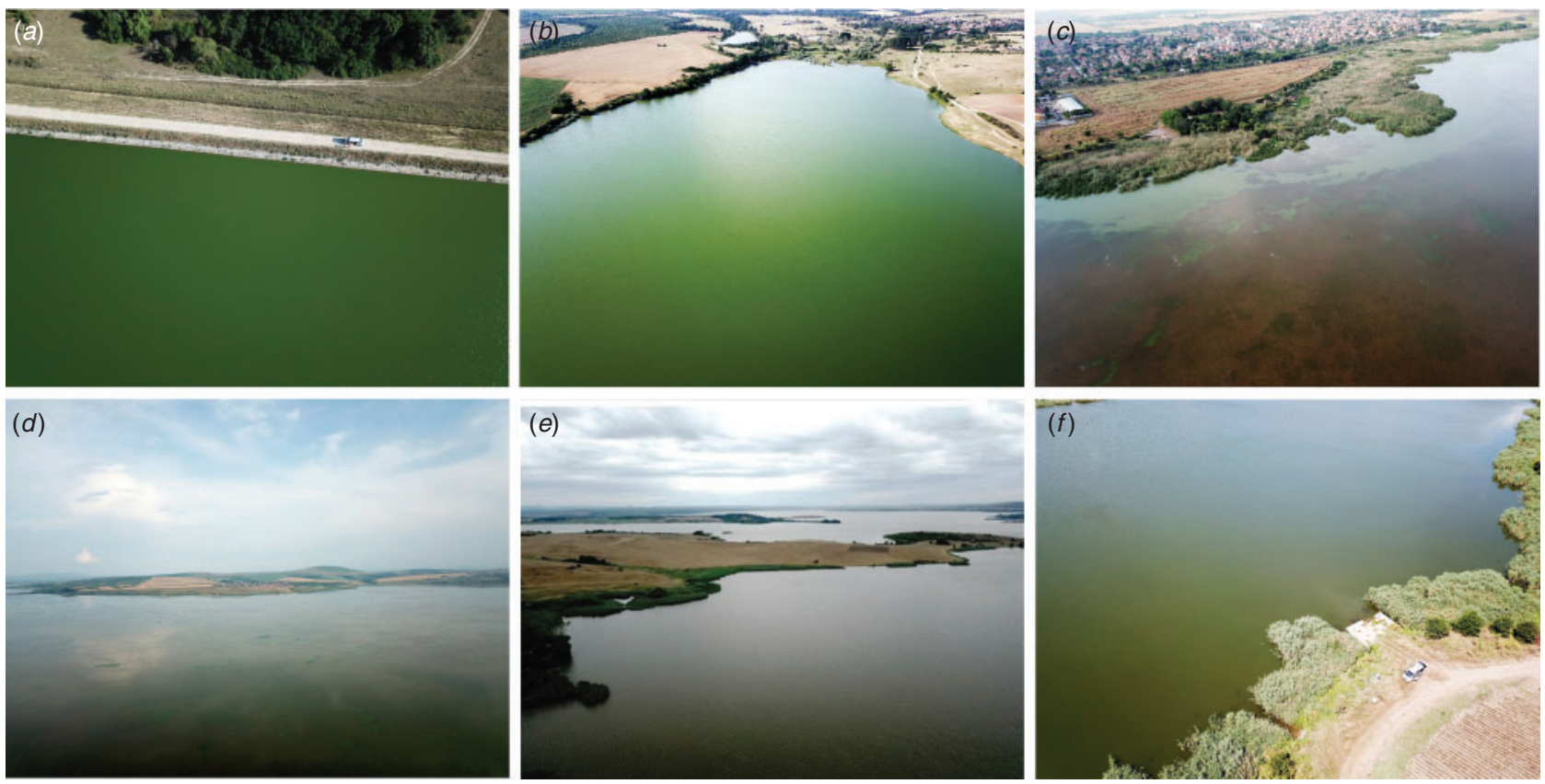

Fig. 2. Aerial photographs taken by drones of some of the Bulgarian water bodies studied (June 2018): (a) Site 1 in Sinyata Reka Reservoir; (b) Site 2 in Sinyata Reka Reservoir; (c) Site 1 of Vaya Lake; $(d)$ Site 3 of Vaya Lake; (e) Site 2 of Mandra Reservoir; ( $f$ ) Site 3 of Durankulak Lake, showing the minibus parked near the small quay used to access the sampling site.

Table 2. Initial ratio matrix for determination of phytoplankton classes biomass ( $\mu \mathrm{g}$ chlorophyll- $a \mathrm{~L}^{-1}$ ) using CHEMTAX

The values are, for each phytoplankton class, the concentration of each pigment to chlorophyll a (chl_a); peri, peridinin; fuco, fucoxanthin; neo, neoxanthin; myxo, myxoxanthophyll; viol, violaxanthin; ddx, diatoxanthin + diadinoxanthin; allo, alloxanthin; lut, lutein; zea, zeaxanthin; echi, echinenone; acar, $\alpha$-carotene; chl_c, chlorophyll-c; chl_b, chlorophyll-b

\begin{tabular}{|c|c|c|c|c|c|c|c|c|c|c|c|c|c|}
\hline Class & peri & fuco & neo & myxo & viol & $\mathrm{ddx}$ & $\begin{array}{c}\text { Pigment } \\
\text { allo }\end{array}$ & lut & zea & echi & chl_c & chl_b & chl_a \\
\hline chlorophytes & 0.000 & 0.000 & 0.033 & 0.000 & 0.030 & 0.000 & 0.000 & 0.174 & 0.023 & 0.000 & 0.000 & 0.273 & 1.000 \\
\hline cryptophytes & 0.000 & 0.000 & 0.000 & 0.000 & 0.000 & 0.000 & 0.396 & 0.000 & 0.000 & 0.000 & 0.100 & 0.000 & 1.000 \\
\hline cyanobacteria_T1 & 0.000 & 0.000 & 0.000 & 0.000 & 0.000 & 0.000 & 0.000 & 0.000 & 0.109 & 0.000 & 0.000 & 0.000 & 1.000 \\
\hline cyanobacteria_T2 & 0.000 & 0.000 & 0.000 & 0.150 & 0.000 & 0.000 & 0.000 & 0.000 & 0.043 & 0.095 & 0.000 & 0.000 & 1.000 \\
\hline euglenophytes & 0.000 & 0.000 & 0.030 & 0.000 & 0.000 & 0.450 & 0.000 & 0.000 & 0.000 & 0.000 & 0.000 & 0.200 & 1.000 \\
\hline
\end{tabular}

reader. The concentrations of the samples are determined by interpolation using a standard curve constructed for each run. For determination of cylindrospermopsin and saxitoxin concentrations in water samples, commercially available ELISA kits were used (Saxitoxin (PSP) ELISA, Microtiter Plate; Abraxis) in combination with a microplate reader (5060-006; LKB, Vienna, Austria).

\section{Results}

During the field trip, 17 sites from nine shallow lowland waterbodies were sampled and their main environmental characteristics were measured (Fig. 1; Table 1). Based on drone observations of the water surface and colour, four sites with visible coloured spots were chosen for targeted sampling of CyanoHABs: Sinyata Reka 1, Vaya 1, Vaya 3 and Durankulak 3 (Fig. 2). The Mandra 2 site could be tentatively added to this category because of the strong wind that started blowing approximately $1 \mathrm{~h}$ before its sampling. The wind caused water mixing in the shallow Mandra Reservoir (up to $2 \mathrm{~m}$ at Sampling sites 1-3), when the Mandra 1 site was sampled (in accordance with our previous studies - Stoyneva 2014, 2016; Stoyneva et al. 2015; Stoyneva-Gärtner et al. 2017) and the use of a drone was impossible. After the wind stopped, the drone was sent over Mandra 2 and Mandra 3 sites. A slight change in water colour with some tiny greenish glares was seen only at the Mandra 2 site (Fig. 2e). A difference in water colour was 


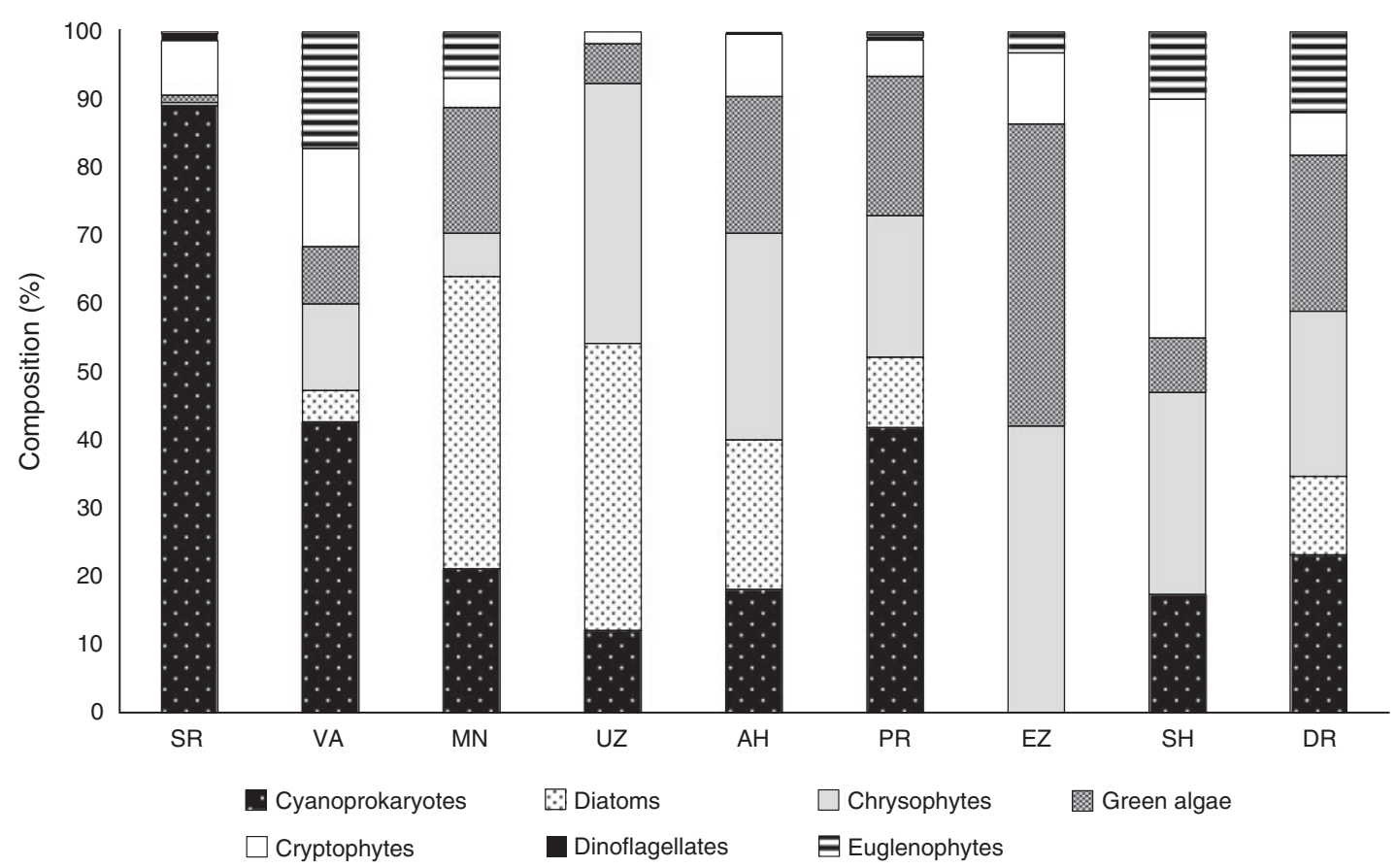

Fig. 3. General phytoplankton composition according to the pigment markers examined by HPLC (expressed as relative percentage abundance of the total biomass) in the Bulgarian water bodies studied. SR, Sinyata Reka Reservoir; VA, Vaya Lake; MN, Mandra Reservoir; UZ, Uzungeren Lake; AH, Aheloy Reservoir; PR, Poroy Reservoir; EZ, Ezerets Lake; SH, Shabla Lake; DR, Durankulak Lake.

visible to the naked eye from the shore at the Durankulak 2 site (also sampled in our previous studies, cited above) without need for a drone.

HPLC data on pigment markers indicate that the phytoplankton of the studied sites primarily comprised cyanoprokaryotes, diatoms and green algae, with a lower contribution of chrysophytes, cryptophytes, euglenophytes and dinoflagellates (Fig. 3).

Phytoplankton composition and abundance varied between the waterbodies studied and between the different sites (Fig. 4). Based on the Chl- $a$ concentration, the Poroy and Aheloy reservoirs and the Shabla and Ezerets lakes were eutrophic (10-25 $\left.\mu \mathrm{g} \mathrm{L}^{-1} \mathrm{Chl}-a\right)$ and all other waterbodies were hypertrophic $\left(>25 \mu \mathrm{g} \mathrm{L}^{-1} \mathrm{Chl}-a\right)$, with highest phytoplankton abundance in Sinyata Reka, Vaya, Mandra and Durankulak (Fig. 4). The contribution of Cyanoprokaryota or Cyanobacteria at each site showed a similar distribution pattern to that seen for the waterbodies, being highest in Sinyata Reka Reservoir and lowest in Shabla and Ezerets lakes (Fig. 4). At all sites chosen by drone, and at the Durankulak 2 site, the contribution of both Chl- $a$ and cyanoprokaryotes was higher compared with the other sites (Fig. 4).

TN ranged between 2.8 and $5.4 \mathrm{mg} \mathrm{L}^{-1}$ and varied slightly between the sites studied in the same waterbody (Table 1). TP ranged between 0.1 and $2.5 \mathrm{mg} \mathrm{L}^{-1}$ (Table 1). There was considerable variation in TP values between the waterbodies studied, but only slight variations between different sites in the same waterbody (Table 1).

The TN : TP ratios (Table 1) indicated strong $\mathrm{N}$ limitation at almost all sites studied (values between 1.8 and 5.6), with the exception of Shabla, where a TN : TP ratio of 51 indicates strong
P limitation, and Ezerets, where a TN:TP ratio of 10.60 indicates that either of the nutrients may be limiting.

The results of the PCA run on environmental variables, Chl- $a$ and the biomass of phytoplankton groups are shown in Fig. 5 . Chl- $a$ and TP were strongly positively correlated with each other, and negatively correlated with Secchi depth, determining the first principal component (PC). Cyanobacterial biomass was strongly correlated with this eutrophication gradient. The second PC was determined primarily by TN, DO and conductivity, which were negatively correlated with diatoms and chrysophytes. Four groups of waterbodies were identified in the lakes ordination (Fig. 5). The grouping of the waterbodies is easy to be explain by their trophic status based on Chl- $a$. The first group contained the hypertrophic inland Sinyata Reka Reservoir and Vaya Lake, both with the highest biomass (mean Chl- $a 116$ and $87 \mu \mathrm{g} \mathrm{L}^{-1}$ respectively) and highest $\mathrm{pH}$ values. The second group contained only the large Mandra Reservoir (average Chl-a $56 \mu \mathrm{g} \mathrm{L}^{-1}$ ), whereas the third group included Uzungeren and Durankulak lakes, with mean Chl- $a$ of 65 and $33 \mu \mathrm{g} \mathrm{L}{ }^{-1}$ respectively. The fourth group was formed by all eutrophic waterbodies: the Aheloy and Poroy reservoirs and the two lakes on the north-coast, Shabla and Ezerets (Chl- $a$ ranging between 9 and $12 \mu \mathrm{g} \mathrm{L}^{-1}$ ).

Toxin analyses revealed the presence of microcystins (MC-RR, MC-YR and MC-LR, but primarily MC-LR) in two of the waterbodies studied (Sinyata Reka and Durankulak), with a difference in their concentrations and type depending on site (Table 3). Cylindrospermopsin was found in Mandra and Vaya, and saxitoxins were recorded in Durankulak, whereas nodularin was not detected in any of the waterbodies (Table 3). 


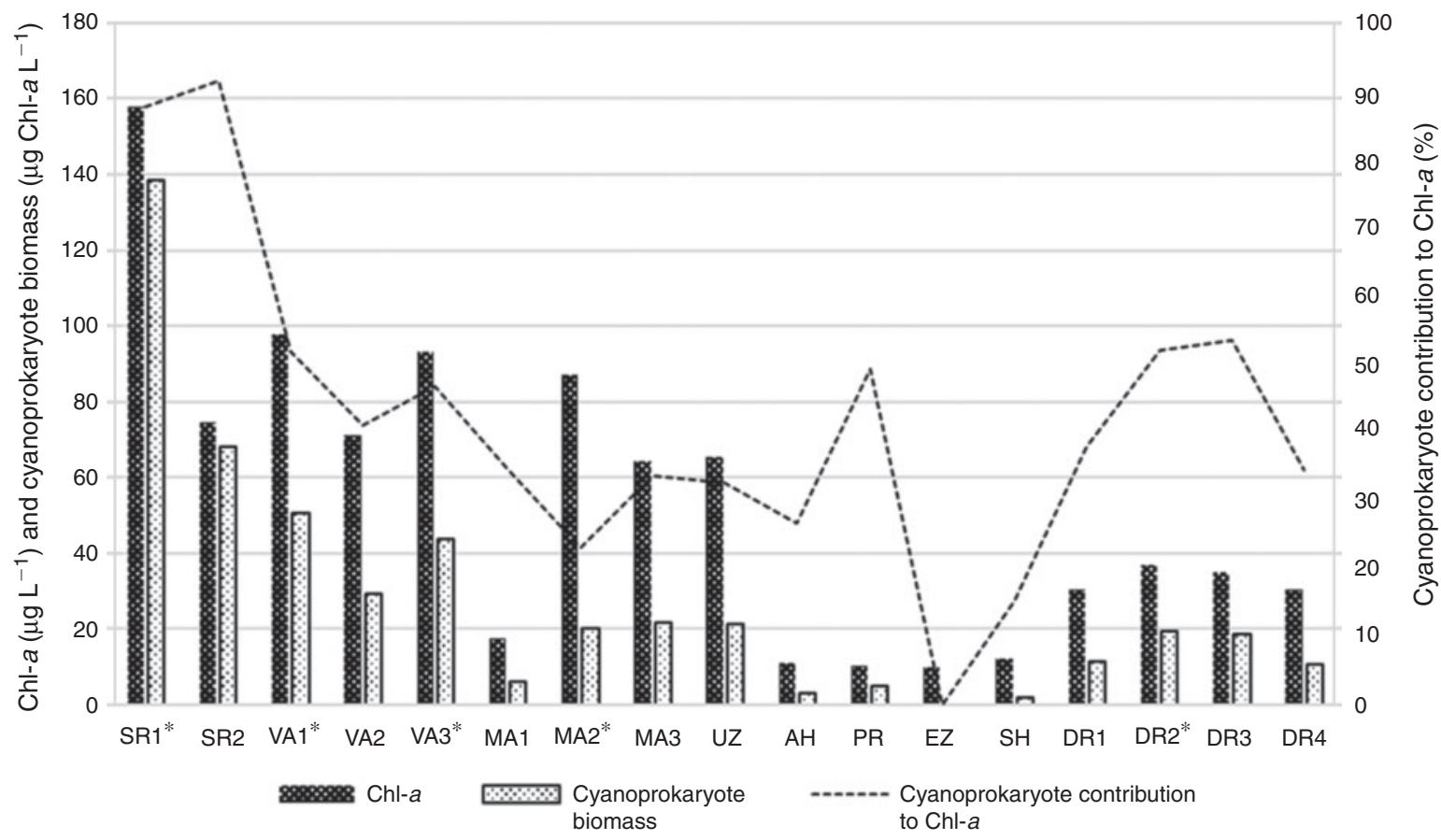

Fig. 4. High performance liquid chromatography (HPLC) data for total chlorophyll (Chl)- $a$ and cyanoprokaryote biomass, and cyanoprokaryote contribution to Chl- $a$ in numbered sites (asterisks indicate that the site was chosen based on drone observations) in the Bulgarian waterbodies studied: SR, Sinyata Reka Reservoir; VA, Vaya Lake; MN, Mandra Reservoir; UZ, Uzungeren Lake; AH, Aheloy Reservoir; PR, Poroy Reservoir; EZ, Ezerets Lake; SH, Shabla Lake; DR, Durankulak Lake.
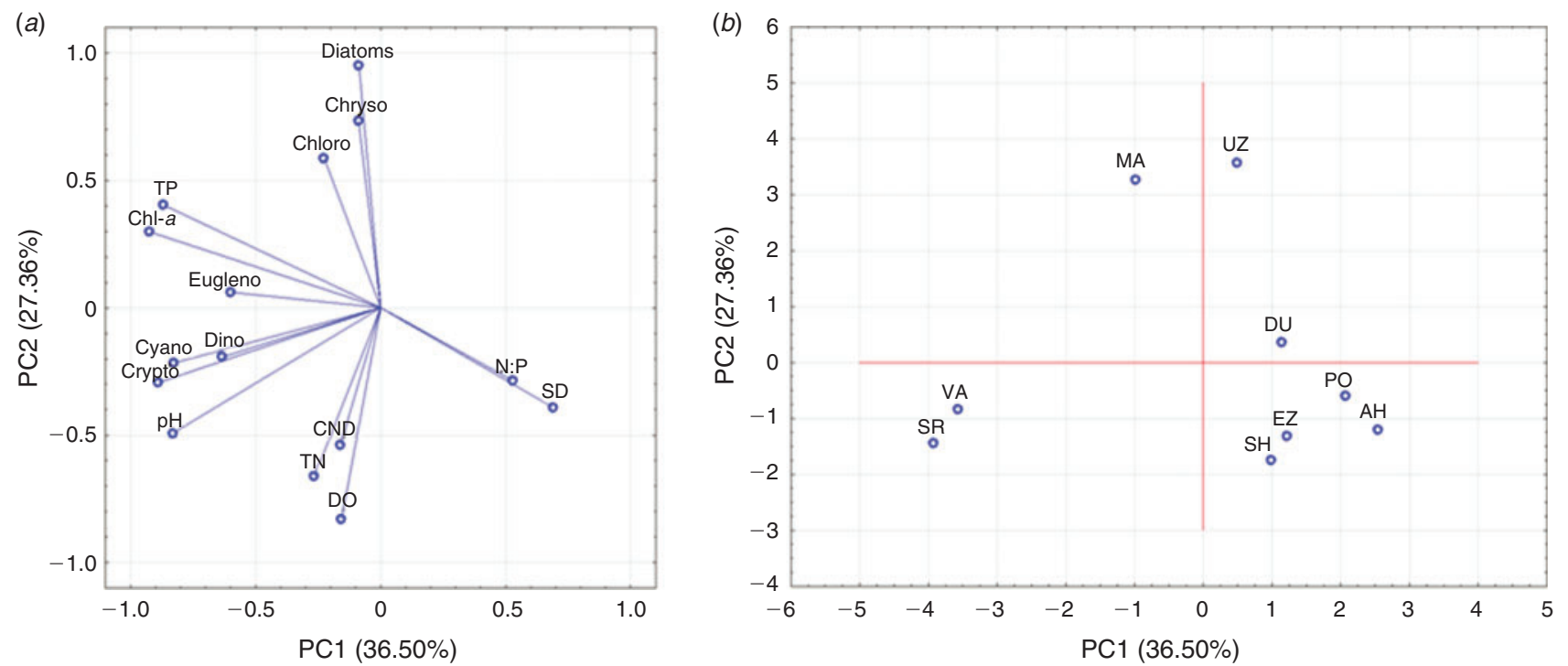

Fig. 5. Results of the principal component analysis on environmental variables and the biomass of phytoplankton groups of nine Bulgarian waterbodies. (a) Ordination of variables on the first two principal components ( $\mathrm{PC} 1, \mathrm{PC} 2$; cumulative inertia $=63.9 \%$ ). Values in parentheses in axis titles indicate the percentage variation explained by each PC. The biomass of the main phytoplankton groups was quantified using CHEMTAX software (CSIRO Marine Laboratories, Mackey et al. 1996). CND, electric conductivity; SD, Secchi depth; DO, dissolved oxygen; $\mathrm{TP}$, total phosphorus; TN, total nitrogen; N: P, ratio of total N to total $\mathrm{P}$; Chl- $a$, chlorophyll- $a$; chryso, chrysophytes; chloro, green algae; eugleno, euglenophytes; cyano, cyanoprokaryotes; crypto, cryptophytes. (b) Ordination of the lakes. SR, Sinyata Reka Reservoir; VA, Vaya Lake; MN, Mandra Reservoir; UZ, Uzungeren Lake; AH, Aheloy Reservoir; PR, Poroy Reservoir; EZ, Ezerets Lake; SH, Shabla Lake; DR, Durankulak Lake. 
Table 3. Cyanotoxins detected in Bulgarian waterbodies (June 2018)

Microcystins (MC-RR, MC-LR, MC-YR) were detected using HPCL (limit of detection (LOD) $0.08-0.15 \mu \mathrm{g} \mathrm{L}^{-1}$ ), whereas saxitoxins and cylindrospermopsin (CSPM) were detected by ELISA (LOD 0.015 and $0.4 \mu \mathrm{g} \mathrm{L}^{-1}$ respectively). IBW, Inventory of Bulgarian Wetlands (Michev and Stoyneva 2007); SA, site abbreviation (asterisks indicate that the site was chosen based on drone observations). Sampling dates are as provided in Table 1

\begin{tabular}{|c|c|c|c|c|}
\hline Waterbody (IBW number) & SA & Microcystins $\left(\mu \mathrm{g} \mathrm{L}^{-1}\right)$ & Saxitoxins $\left(\mu \mathrm{g} \mathrm{L}^{-1}\right)$ & $\overline{\operatorname{CSPM}}\left(\mu \mathrm{g} \mathrm{L}^{-1}\right)$ \\
\hline \multirow[t]{2}{*}{ Sinyata Reka Reservoir (IBW1793) } & SR1* & MC-RR, 0.09; MC-LR, 0.3 & $<$ LOD & $<$ LOD \\
\hline & $\mathrm{SR} 2$ & $<\mathrm{LOD}$ & $<\mathrm{LOD}$ & $<$ LOD \\
\hline \multirow[t]{3}{*}{ Vaya Lake (IBW0191) } & VA $1 *$ & $<\mathrm{LOD}$ & $<\mathrm{LOD}$ & 0.1 \\
\hline & VA2 & $<\mathrm{LOD}$ & $<\mathrm{LOD}$ & $<\mathrm{LOD}$ \\
\hline & VA3* & $<\mathrm{LOD}$ & $<\mathrm{LOD}$ & $<\mathrm{LOD}$ \\
\hline \multirow[t]{3}{*}{ Res. Mandra Reservoir (IBW1720) } & MN1 & $<\mathrm{LOD}$ & $<$ LOD & $<$ LOD \\
\hline & MN2* & $<\mathrm{LOD}$ & $<\mathrm{LOD}$ & 0.1 \\
\hline & MN3 & $<\mathrm{LOD}$ & $<\mathrm{LOD}$ & $<\mathrm{LOD}$ \\
\hline Uzungeren Lake (IBW0710) & $\mathrm{UZ}$ & $<\mathrm{LOD}$ & $<$ LOD & $<$ LOD \\
\hline Poroy Reservoir (IBW3038) & PR & $<\mathrm{LOD}$ & $<\mathrm{LOD}$ & $<\mathrm{LOD}$ \\
\hline Aheloy Reservoir (IBW3032) & $\mathrm{AH}$ & $<\mathrm{LOD}$ & $<\mathrm{LOD}$ & $<\mathrm{LOD}$ \\
\hline Ezerets Lake (IBW0233) & $\mathrm{EZ}$ & $<\mathrm{LOD}$ & $<\mathrm{LOD}$ & $<\mathrm{LOD}$ \\
\hline Shabla Lake (IBW0219) & SH & $<\mathrm{LOD}$ & $<\mathrm{LOD}$ & $<\mathrm{LOD}$ \\
\hline \multirow[t]{4}{*}{ Durankulak Lake (IBW0216) } & DR1 & $<\mathrm{LOD}$ & $<\mathrm{LOD}$ & $<\mathrm{LOD}$ \\
\hline & DR2 & MC-YR, 0.2; MC-LR, 0.2 & $<$ LOD & $<$ LOD \\
\hline & DR3* & MC-LR, 0.1 & 0.015 & $<\mathrm{LOD}$ \\
\hline & DR4 & $<\mathrm{LOD}$ & $<\mathrm{LOD}$ & $<\mathrm{LOD}$ \\
\hline
\end{tabular}

\section{Discussion}

The results of this study prove the eutrophic to hypertrophic character of the chosen waterbodies, as reported previously (Stoyneva-Gärtner et al. 2017; Descy et al. 2018 and references therein). In these conditions, the high relative proportion of Cyanoprokaryota (Cyanobacteria) in the phytoplankton biomass at almost all sites studied is easy to explain and confirms previous knowledge on their widespread distribution, high diversity and abundance in the region studied (Stoyneva 2000a, 2003; Pavlova et al. 2007; Dimitrova et al. 2014a, 2014b; Stoyneva 2014; Stoyneva-Gärtner et al. 2017; Descy et al. 2018). The low water transparency and high $\mathrm{pH}$ detected during the study (Table 1) correspond to both total phytoplankton and cyanoprokaryote abundance (Fig. 3, 4) and are in general accordance with our previous results for most of these waterbodies obtained after processing by multivariate analyses (Stoyneva 2014; Stoyneva et al. 2015; StoynevaGärtner et al. 2017). Again, cyanobacterial abundance increased with $\mathrm{P}$ concentrations, thus confirming our previous results in Bulgarian wetlands (Stoyneva 2014; Stoyneva et al. 2015; Stoyneva-Gärtner et al. 2017). Therefore, it is likely that in shallow Bulgarian waterbodies TP is the main cause of cyanobacterial abundance rather than any other measured variable. Although collected during one sampling campaign, the data from this study are in accordance with the knowledge of the general environmental driving forces that allow cyanoprokaryotes to outcompete other phytoplankton in eutrophic to hypertrophic shallow standing waterbodies, such as high temperatures, high $\mathrm{pH}$ and mainly high $\mathrm{P}$ (Downing et al. 2001; Carvalho et al. 2013; Descy et al. 2016). In contrast, in the present study TN was not correlated with TP and Chl- $a$, and does not appear as a key determinant of cyanoprokaryote biomass.
Considering the studies cited above and the shallow character of the holo- to polymictic lowland wetlands studied, the relatively small variation in spatial distribution of the phytoplankton biomass, as well as the related Chl- $a$ content and cyanoprokaryote biomass in the studied waterbodies are to be expected. That was confirmed by the aerial photographs taken in the field by the drone using uncorrected photographs, without any attempt to mathematically correct the data for surface reflections. The four exceptional cases of stronger water colour in single sites at Sinyata Reka, Vaya and Durankulak (Fig. 2a-d,f) and the less visible spot in Mandra fitted well with the HPLC data on pigment composition and phytoplankton biomass (Fig. 3, 4). The spots observed by drone and confirmed after local sampling and processing of the material collected in the beginning of summer (June 2018) were in accordance with previous knowledge that blooms commonly start at sites offering the best conditions (primarily favourable light and nutrient availability), known as hot spots or fronts of productivity (Oliver and Ganf 2000; Gons et al. 2005). A shortcoming of drone application was detected when the Mandra Reservoir was sampled during and after a strong wind, when the water surface and colour looked more homogeneous. However, even in this case, the drone observations helped identify the initial front of a CyanoHAB (Fig. 2e).

The toxins detected (Table 3 ) confirmed our previous findings of microcystins (especially MC-LR, considered the most dangerous type) in Durankulak (Pavlova et al. 2006, 2013, 2014, 2015; Pavlova 2007; Stoyneva-Gärtner et al. 2017) and are the first reports of microcystins in Sinyata Reka Reservoir. The finding of saxitoxins is the first for Durankulak. During this study the presence of cylindrospermopsin in Bulgaria was proved by reliable methods for the first time. This cyanotoxin was long ago thought to occur in Bulgarian waters 
(Pavlova et al. 2014; Stoyneva 2014) based on observations of the widening distribution of its main causative agent, namely Raphidiopsis raciborskii (Woloszynska) Aguilera, Berrendero Gómez, Kastovsky, Echenique et Salerno (Syn. Cylindrospermopsis raciborskii (Woloszynska) Seenayya et Subba Raju), in Bulgaria and particularly after the species was detected in Vaya and Mandra (Dimitrova et al. 2014b; Stoyneva 2016; Kokociński et al. 2017b; Stoyneva-Gärtner et al. 2017). The presence of cylindrospermopsin, produced by heterocytous algae with strong $\mathrm{N}$-fixation ability, is in accordance with the $\mathrm{N}$ limitation of the waterbodies studied, and of Mandra and Vaya in particular.

The low concentrations of all toxins found and their detection at separate sites (Table 3) are easily explained by the atypical (for the season) strong rains and floods that started during the sampling week just after a long (also untypical for the country) early period of warm weather and drought in April and May of 2018. Although recorded in low concentrations, almost all toxic substances were found at the sampling sites chosen based on drone observations, which differed visually in terms of water colour and were proven to contain a higher abundance of cyanoprokaryote compared with the other sampling sites (Fig. 2, 4; Table 3).

The results of this study proved the risk in the shallow lowland waterbodies of the occurrence of CyanoHABs and show the considerable potential of using modern remote methods and HPLC in studies and monitoring of CyanoHABs. Despite possible limitations of the field application of a drone because of meteorological conditions (e.g. wind, rain), the results of this study confirm the importance of remote observations for choosing proper sampling sites. Other reasons favouring the use of drones are that they are easy and fast to use and they are small and easy to transport during field trips. Considering the high number of wetlands over Bulgaria ( $~ 9000$ according to Michev and Stoyneva 2007), we would strongly recommend the further use of drones and the pigment technique in studies of phytoplankton biomass and composition to greatly increase the speed of the field work; these techniques are very efficient in terms of data acquisition and provide valuable information.

\section{Author contribution}

The first two authors contributed equally to the preparation of the work and of the manuscript.

\section{Conflicts of interest}

The authors declare that they have no conflicts of interest.

\section{Declaration of funding}

This study was supported by financial support from the Scientific Research Fund of the Bulgarian Ministry of Education through Project DN-13-9/17.12.2017.

\section{References}

Ballot, A., Bernard, C., and Fastner, J. (2017). Saxitoxin and analogues. In 'Handbook of Cyanobacterial Monitoring and Cyanotoxin Analysis'. (Eds J. Meriluoto, L. Spoof, and G. A. Codd.) pp. 148-154. (Wiley: Singapore.)
Boon, M. A., Greenfield, R., and Tefamichael, S. (2016). Wetland assessment using unmanned aerial vehicle (UAV) photogrammetry. The International Archives of the Photogrammetry, Remote Sensing and Spatial Information Sciences XLI, 781-788. doi:10.5194/ ISPRSARCHIVES-XLI-B1-781-2016

Carmichael, W. W. (1994). The toxins of cyanobacteria. Scientific American 270, 78-86. doi:10.1038/SCIENTIFICAMERICAN0194-78

Carmichael, W. W., and Boyer, G. L. (2016). Health impacts from cyanobacteria harmful algae blooms: implications for the North American Great Lakes. Harmful Algae 54, 194-212. doi:10.1016/J.HAL.2016.02. 002

Carvalho, L., McDonald, C., de Hoyos, C., Mischke, U., Phillips, G., Borics, G., Poikane, S., Skjelbred, B., Solheim, A. L., Van Wichelen, J., and Cardoso, A. C. (2013). Sustaining recreational quality of European lakes, minimizing the health risks from algal blooms through phosphorus control. Journal of Applied Ecology 50(2), 315-323. doi:10.1111/13652664.12059

Catherine, A., Bernard, C., Spoof, L., and Bruno, M. (2017). Microcystins and nodularins. In 'Handbook of Cyanobacterial Monitoring and Cyanotoxin Analysis'. (Eds J. Meriluoto, L. Spoof, and G. A. Codd.) pp. 109-126. (Wiley: Singapore.)

Chorus, I., and Bartram, J. (Eds) (1999). 'Toxic Cyanobacteria in Water. A Guide to their Public Health Consequences, Monitoring and Management.' (WHO and CRC Press: Boca Raton, FL, USA.)

Codd, G. A. (1995). Cyanobacterial toxins: occurrence, properties and biological significance. Water Science and Technology 32, 149-156. doi:10.2166/WST.1995.0177

Codd, G. A., Bell, S. G., and Brooks, W. P. (1989). Cyanobacterial toxins in water. Water Science and Technology 21, 1-13. doi:10.2166/WST.1989. 0071

Codd, G. A., Bell, S. G., Kaya, K., Ward, C. J., Beattie, K. A., and Metcalf, J. S. (1999). Cyanobacterial toxins, exposure routes and human health. European Journal of Phycology 34, 405-415. doi:10.1080/ 09670269910001736462

Codd, G. A., Morrison, L. F. M., and Metcalf, J. S. (2005a). Cyanobacterial toxins: risk management for health protection. Toxicology and Applied Pharmacology 203, 264-272. doi:10.1016/J.TAAP.2004.02.016

Codd, G. A., Lindsay, J., Young, F. M., Morrison, L. F. M., and Metcalf, J. S. (2005b). Harmful cyanobacteria. From mass mortalities to management measures. In 'Harmful Cyanobacteria'. (Eds J. Huisman, H. C. P. Matthijs, and P. M. Visser.) pp. 1-23. (Springer: Dordrecht, Netherlands.)

Descy, J. P. (2017). SOP5: estimation of cyanobacteria biomass by marker pigment analysis. In 'Handbook of Cyanobacterial Monitoring and Cyanotoxin Analysis', 1 st edn. (Eds J. Meriluoto, J. Codd, and L. Spoof.) pp. 343-349. (Wiley: Singapore.)

Descy, J.-P., Higgins, H. W., Mackey, D. J., Hurley, J. P., and Frost, T. M. (2000). Pigment ratios and phytoplankton assessment in northern Wisconsin lakes. Journal of Phycology 36, 274-286. doi:10.1046/ J.1529-8817.2000.99063.X

Descy, J. P., Leprieur, F., Pirlot, S., Leporcq, B., Van Wichelen, J., Peretyatko, A., Teissier, S., Codd, G. A., Triest, L., Vyverman, W., and Wilmotte, A. (2016). Identifying the factors determining blooms of cyanobacteria in a set of shallow lakes. Ecological Informatics 34, 129138. doi:10.1016/J.ECOINF.2016.05.003

Descy, J.-P., Stoyneva-Gärtner, M. P., Uzunov, B. A., Dimitrova, P. H., Pavlova, V. Ts., and Gärtner, G. (2018). Studies on cyanoprokaryotes of the water bodies along the Bulgarian Black Sea Coast (1890-2017): a review, with special reference to new, rare and harmful taxa. Acta Zoologica Bulgarica 11, 43-52.

Dimitrova, R. E., Nenova, E. P., Uzunov, B. A., Shihiniova, M. D., and Stoyneva, M. P. (2014a). Phytoplankton abundance and structural parameters of the critically endangered protected area Vaya Lake (Bulgaria). Biotechnology, Biotechnological Equipment 28(5), 871-877. doi:10.1080/13102818.2014.947718 
Dimitrova, R. E., Nenova, E. P., Uzunov, B. A., Shihiniova, M. D., and Stoyneva, M. P. (2014b). Phytoplankton composition of Vaya Lake (2004-2006). Bulgarian Journal of Agricultural Science 1, 165-172.

Dimitrova, P. H., Stoyneva-Gärtner, M. P., Uzunov, B. A., and Gärtner, G. (2018). Review of the algological studies of Bulgarian Black Sea coastal water bodies (1890-2017) with special attention to the newly described and threatened species. Acta Zoologica Bulgarica 11, 27-42.

Downing, J. A., Watson, S. B., and McCauley, E. (2001). Predicting cyanobacteria dominance in lakes. Canadian Journal of Fisheries and Aquatic Sciences 58(10), 1905-1908. doi:10.1139/F01-143

Elliott, J. A. (2012). Is the future blue-green? A review of the current model predictions of how climate change could affect pelagic freshwater cyanobacteria. Water Resources Journal 46, 1364-1371.

Forsberg, C., Ryding, S. O., Claesson, A., and Forsberg, A. (1978). Water chemical analyses and/or algal assay? Sewage efficient and polluted water studies. Mitteilungen - Internationale Vereinigung Für Theoretische und Angewandte Limnologie 21, 352-363.

Gons, H. J., Hakvoort, H., Peters, S. M. W., and Simis, S. G. H. (2005). Optical detection of cyanopbacterial blooms. Shipboard observation and remote sensing. In 'Harmful Cyanobacteria.' (Eds J. Huisman, H. C. P. Matthijs, and P. M. Visser.) pp. 177-199. (Springer: Dordrecht, Netherlands.)

Graham, L. E., Graham, J. M., and Wilcox, L. W. (2009). 'Algae.' (Benjamin Cummings: Munich, Germany.)

International Organization for Standardization (2005). ISO 20179:2005. Water quality - determination of microcystins - method using solid phase extraction (SPE) and high performance liquid chromatography (HPLC) with ultraviolet (UV) detection. ISO/TC 147/SC 2 Physical, Chemical and Biochemical Methods, Technical Committee, International Organization for Standardization. Available at https://www.iso. org/standard/34098.html [Verified 6 May 2019].

Jeffrey, S. W., Mantoura, R. F. C., and Wright, S. W. (1997). 'Phytoplankton Pigments in Oceanography: Guidelines to Modern Methods.' (Scientific Committee on Organic Research, UNESCO: Paris, France.)

Jung, S., Cho, H., Kim, D., Kim, K., Han, J.-I., and Muyng, H. (2017). Development of algal bloom removal system using unmanned aerial vehicle and surface vehicle. IEEE Access - Practical Innovations, Open Solutions 5, 22166-22176. doi:10.1109/ACCESS.2017.2764328

Kokociński, M., Cameán, M. A., Carmeli, S., Guzmán-Guillén, R., Jos, A., Mankiewicz-Boczek, J., Metcalf, S. J., Moreno, M. I., Prieto, I. A., and Sukenik, A. (2017a). Cylindrospermopsin and congeners. In 'Handbook of Cyanobacterial Monitoring and Cyanotoxin Analysis', 1st edn. (Eds J. Meriluoto, L. Spoof, and G. A. Codd.) pp. 127-137. (Wiley: Singapore.)

Kokociński, M., Akçaalan, R., Salmaso, N., Stoyneva-Gärtner, M., and Sukenik, A. (2017b). Expansion of alien/invasive cyanobacteria. In 'Handbook of Cyanobacterial Monitoring and Cyanotoxin Analysis'. (Eds J. Meriluoto, L. Spoof, and G. A. Codd.) pp. 28-40. (Wiley: Singapore.)

Liyanage, H. M., Arachchi, D. N., Abeysekara, T., and Guneratne, L. (2016). Toxicology of freshwater cyanobacteria. Journal of Environmental Science and Health - C. Environmental Carcinogenesis and Ecotoxicology Reviews 34, 137-168. doi:10.1080/10590501.2016.1193923

Mackey, M. D., Mackey, D. J., Higgins, H. W., and Wright, S. W. (1996). CHEMTAX - a program for estimating class abundances from chemical markers: application to HPLC measurements of phytoplankton. Marine Ecology Progress Series 144, 265-283. doi:10.3354/MEPS144265

Maršálek, B., Bláha, L., and Hindák, F. (2000). Review of toxicity of cyanobacteria in Slovakia. Biologia 55, 645-652.

Merel, S., Walker, D., Chicana, R., Snyder, S., Baurès, E., and Thomas, O. (2013). State of knowledge and concerns on cyanobacterial blooms and cyanotoxins. Environment International 59, 303-327. doi:10.1016/ J.ENVINT.2013.06.013

Meriluoto, J., and Codd, G. A. (Eds) (2005). 'TOXIC: Cyanobacterial Monitoring and Cyanotoxin Analysis.' (Åbo Akademi University Press: Turku, Finland.)
Metcalf, J. S., and Codd, G. A. (2012). Cyanotoxins. In 'Ecology of Cyanobacteria II: Their Diversity in Space and Time'. (Ed. B. A. Whitton.) pp. 651-675. (Springer Science +Business Media BV: London, UK.)

Michev, T. M., and Stoyneva, M. P. (Eds) (2007). 'Inventory of Bulgarian Wetlands and Their Biodiversity. Part 1: Non-Lotic Wetlands.' (Publishing House Elsi-M: Sofia, Bulgaria.)

Mitrovic, S. M., Allis, O., Furey, A., and James, K. J. (2005). Bioaccumulation and harmful effects of microcystin-LR in the aquatic plants Lemna minor and Wolffia arrhiza and the filamentous alga Cladophora fracta. Ecotoxicology and Environmental Safety 61, 345-352. doi:10.1016/ J.ECOENV.2004.11.003

Mowe, M. A. D., Porojan, C., Abbas, F., Mitrovic, S. M., Lim, R. P., Furey, A., and Yeo, D. C. J. (2015). Rising temperatures may increase growth rates and microcystin production in tropical Microcystis species. Harmful Algae 50, 88-98. [Published erratum appears in Harmful Algae 2017, 63, 205-206]. doi:10.1016/J.HAL.2015.10.011

Oliver, R. L., and Ganf, G. G. (2000). Freshwater blooms. In 'The Ecology of Cyanobacteria. Their Diversity in Time and Space'. (Eds B. A. Whitton and M. Potts.) pp. 149-194. (Kluwer Academic Publishers: Dordrecht, Netherlands.)

Overbeck, J. (1988). Ecosystem concepts. In 'Guidelines of Lake Management. Vol. 1. Principles of Lake Management’. (Eds S. E. Jørgensen and R. A. Vollenweider.) pp. 19-36. (International Lake Environment Committee and United Nations Environment Programme: Shiga, Japan.)

Paerl, H. W. (2001). Mitigating toxic planktonic cyanobacterial blooms in aquatic ecosystems facing increasing anthropogenic and climate pressures. Toxins 10, 1124-1134.

Paerl, H. W., Pinckney, J. L., Dyble, J., Valdes, L. M., Piehler, M. F., and Moisander, P. H. (2003). Phytoplankton photopigments as indicators of estuarine and coastal eutrophication. Bioscience 53(10), 953-964. doi:10.1641/0006-3568(2003)053[0953:PPAIOE]2.0.CO;2

Paerl, H. W., Hall, N. S., and Calandrino, E. S. (2011). Controlling harmful cyanobacterial blooms in a world experiencing anthropogenic and climatic-induced change. The Science of the Total Environment 409, 1739-1745. doi:10.1016/J.SCITOTENV.2011.02.001

Pavlova, V. (2007). Hygiene and analytical aspects of microcystins occurrence in surface water. Ph.D. Thesis, National Center of Public Health Protection, Sofia, Bulgaria. [In Bulgarian].

Pavlova, V., Babica, P., Todorova, D., Bratanova, Z., and Maršalek, B. (2006). Contamination of some reservoirs and lakes in Republic of Bulgaria by microcystins. Acta Hydrochimica et Hydrobiologica 34 (5), 437-441. doi:10.1002/AHEH.200600641

Pavlova, V., Stoyneva, M., Babica, P., Kohoutek, J., and Bratanova, Z. (2007). Microcystins contamination and cyanoprokaryote blooms in some coastal Bulgarian wetlands. In 'Conference Preprint Book of Second International Conference and Exhibition of Water Resources, Technologies and Services', 6-7 June 2007, Sofia, Bulgaria. pp. 221226. (Bulaqua: Sofia, Bulgaria.)

Pavlova, V., Stoyneva, M., and Bratanova, Z. (2013). Cyanoprokaryotes (Cyanobacteria) and cyanotoxins in some Bulgarian reservoirs. Journal of Balkan Ecology 16(3), 257-260.

Pavlova, V., Stoyneva, M., Georgieva, V., Donchev, D., Spoof, L., Meriluoto, J., Bratanova, Z., and Karadjova, I. (2014). New records of microcystins in some Bulgarian water bodies of health and conservational importance. Journal of Water Resource and Protection 6, 446453. doi:10.4236/JWARP.2014.65044

Pavlova, V., Stoyneva-Gärtner, M., Uzunov, B., Bratanova, Z., Lazarova, A., and Karadjova, I. (2015). Microcystins-LR, -YR and -RR in six Bulgarian water bodies of health and conservational importance (2012-2014). Journal of Water Resource and Protection 7, 13751386. doi:10.4236/JWARP.2015.716111

Petkoff, S. (1898). Contribution to the investigation of Bulgarian singlecelled green freshwater algae. Periodichno Spisanie Bulgarsko Knizhovno Druzhestvo 57, 111-135. [In Bulgarian] 
Ragueno, N., Ford, R., and Vodacek, A. (2017). Investigating harmful algal blooms using: satellites, drones, boats, citizen science. In '2017 STRATUS Workshop', 19-20 October 2017, Rochester, NY, USA. pp. 1-22. Available at http://proceedings.esri.com/library/userconf/ proc17/papers/2017_488.pdf [Verified 4 April 2019].

Reynolds, C. S., Huszar, V., Kruk, C., Naselli-Flores, L., and Melo, S. (2002). Towards a functional classification of the freshwater phytoplankton. Journal of Plankton Research 24(5), 417-428. doi:10.1093/ PLANKT/24.5.417

Roelke, D., and Buyukates, Y. (2001). The diversity of harmful algal bloom-triggering mechanisms and the complexity of bloom initiation. Human and Ecological Risk Assessment 7, 1347-1362. doi:10.1080/ 20018091095041

Salmaso, N., Bernard, C., Humbert, J. F., Akçalaan, R., Albay, M., Ballot, A., Catherine, A., Fastner, J., Häggqvist, K., Horecká, M., Izydorszyk, K., Köker, L., Komárek, J., Maloufi, S., Mankiewisz-Boszek, J., Metcalf, S. J., Quesada, A., Quiblier, C., and Yéprémian, C. (2017). Basic guide to detection and monitoring of potentially toxic cyanobacteria. In 'Handbook of Cyanobacterial Monitoring and Cyanotoxin Analysis', 1st edn. (Eds J. Meriluoto, L. Spoof, and G. A. Codd.) pp. 46-49. (Wiley: Singapore.)

Sarmento, H., and Descy, J.-P. (2008). Use of marker pigments and functional groups for assessing the status of phytoplankton assemblages in lakes. Journal of Applied Phycology 20, 1001-1011. doi:10.1007/ S10811-007-9294-0

Schlüter, L., Lauridsen, T. L., Krogh, G., and Jørgensen, T. (2006). Identification and quantification of phytoplankton groups in lakes using new pigment ratios - a comparison between pigment analysis by HPLC and microscopy. Freshwater Biology 51, 1474-1485. doi:10.1111/ J.1365-2427.2006.01582.X

Srivastava, A., Singh, S., Ahn, C. Y., Oh, H. M., and Asthana, R. K. (2013). Monitoring approaches for a toxic cyanobacterial bloom. Environmental Science \& Technology 47, 8999-9013. doi:10.1021/ES401245K

Stoyneva, M. P. (2000a). Algological studies of Bulgarian coastal wetlands. I. Species composition of the phytoplankton of Durankulak and ShablaEzeretz lakes. In "Annual of Sofia University "St Kliment Ohridski", Faculty of Biology, Book 2 - Botany 91'. pp. 27-48. (St Kliment Ohridski University Press: Sofia, Bulgaria.)

Stoyneva, M. P. (2000b). Planktic green algae of Bulgarian coastal wetlands. Hydrobiologia 438, 25-41. doi:10.1023/A:1004105811210

Stoyneva, M. P. (2003). Steady-state phytoplankton assemblages in shallow Bulgarian wetlands. Hydrobiologia 502, 169-176. doi:10.1023/B:HYDR. 0000004279.59719.7E

Stoyneva, M. P. (2014). Contribution to the studies of the biodiversity of hydro- and aerobiontic prokaryotic and eukaryotic algae in Bulgaria. D.Sc. Thesis, Sofia University 'St Kliment Ohridski', Sofia, Bulgaria. [In Bulgarian, English summary].
Stoyneva, M. P. (2016). Allochtonous planctonic algae recorded in Bulgaria during the last 25 years and their possible dispersal agents. Hydrobiologia 764, 53-64. doi:10.1007/S10750-015-2334-X

Stoyneva, M. P., Traykov, I. T., Tosheva, A. G., Uzunov, B. A., Zidarova, R. P., and Descy, J. P. (2015). Comparison of ecological state/potential assessment of 19 Bulgarian water bodies based on macrophytes and phytoplankton (2011-2012). Biotechnology Equipment 29, S33-S38. doi:10.1080/13102818.2015.1047200

Stoyneva-Gärtner, M. P., Descy, J.-P., Latli, A., Uzunov, B., Pavlova, V., Bratanova, Zl., Babica, P., Maršálek, B., Meriluoto, J., and Spoof, L. (2017). Assessment of cyanoprokaryote blooms and of cyanotoxins in Bulgaria in a 15-years period (2000-2015). Advances in Oceanography and Limnology 8(1), 131-152. doi:10.4081/AIOL.2017.6320

Van Dolah, F. M., Roelke, D., and Greene, R. M. (2001). Health and ecological impacts of harmful algal blooms: risk assessment needs. Human and Ecological Risk Assessment 7, 1329-1345. doi:10.1080/ 20018091095032

Van Wichelen, J., van Gremberghe, I., Vanormelingen, P., Debeer, A.-E., Leporcq, B., Menzel, D., Codd, G. A., Descy, J.-P., and Vyverman, W. (2010). Strong effects of amoebae grazing on the biomass and genetic structure of a Microcystis bloom (Cyanobacteria). Environmental Microbiology 12(10), 2797-2813.

Vollenweider, R. A. (1993). Global problems of eutrophication and its control. In 'Conservation and Management of Lakes (Symposia Biologica Hungarica 38)’. (Eds J. Sálanki and S. Herodek.) pp. 19-42. (Akadémiai Kiadó: Budapest, Hungary.)

Vollenweider, R. A., and Kerekes, J. (1982). 'Eutrophication of Waters. Monitoring, Assessment and Control.' (OECD: Paris, France.)

Walker, H. C. (2015). 'Harmful Algal Blooms in Drinking Water. Removal of Cyanobacterial Cells and Toxins.' (CRC Press: Boca Raton, FL, USA.)

Whitton, B. A., and Potts, M. (2012). Introduction to the Cyanobacteria. In 'Ecology of Cyanobacteria II: Their Diversity in Space and Time'. (Ed. B. A. Whitton.) pp. 1-14. (Springer: London, UK.)

Williams, A. (2014). Seek \& destroy. Combating algal blooms with unmanned ultrasonic technology. Water and Wastewater International. Available at https://www.lgsonic.com/wp-content/uploads/Water-Wastewater-International.pdf [Verified 15 September 2018].

World Health Organization (1998). 'Guidelines for Drinking-Water Quality, Health Criteria and other Supporting Information. 2nd edn. Addendum to Vol. 2.' (WHO: Geneva, Switzerland.)

Wright, S. W., and Jeffrey, S. W. (2006). Pigment markers for phytoplankton production. In 'Marine Organic Matter: Biomarkers, Isotopes and DNA'. (Ed. J. H. Volhman.) pp. 71-104. (Springer Verlag: Berlin, Germany.)

Handling Editor: Daniel Roelke 